How to cite: Ilie, N., Apostol, L., Axinte, A.-D., Beteringhe, A. (2021) Application of the 'Hess-Brezowsky' Classification to the Identification of Extreme Precipitations in Northern Part of Moldova. 2021 "Air and WaterComponents of the Environment" Conference Proceedings, Cluj-Napoca, Romania, p. 21-32, DOI: 10.24193/AWC2021_03.

\title{
APPLICATION OF THE 'HESS-BREZOWSKY' CLASSIFICATION TO THE IDENTIFICATION OF EXTREME PRECIPITATIONS IN NORTHERN PART OF MOLDOVA
}

\author{
Nicolae ILIE ${ }^{1,2}$, Liviu APOSTOL ${ }^{2}$, Aurel-Dănuț AXINTE ${ }^{1}$, Andreea \\ BETERINGHE ${ }^{1,3}$
}

DOI: $10.24193 / A W C 2021 \_03$

\begin{abstract}
Due to climate change, important attention was paid to the precipitations amounts over Moldavia's northern part. To point out the rainy air-circulation types was used the 'Hess-Brezowsy' Grosswetterlagen system (HBGWL) with 29 types of classifying European synoptic regimes of the 2000 to 2018 period at the reference weather stations of Bacău (184 m), Botoșani (161 m), Ceahlău-Toaca (1897 m), Iași (102 m), and Suceava $(350 \mathrm{~m})$. The highest amounts of precipitations annually from 2000 to 2018 in Romania's northeastern part were associated with the retrogressive cyclones. Therefore, on a background of the northeastern, cyclonic type (NEZ), there were recorded $53.45 \mathrm{~mm}$, followed by High Scandinavia-Iceland, the ridge over Central Europe (HNFA), with $48.14 \mathrm{~mm}$, and those from East in cyclonic type, with $44.03 \mathrm{~mm}$. All the high over Central Europe (HM) weather types were associated with the lowest precipitations, only $1.71 \mathrm{~mm}$. Also, small amounts of precipitations in the southwestern and south background, both of them into an anti-cyclonic type (SWA, SA), with $2.56 \mathrm{~mm}$, respectively, $2.92 \mathrm{~mm}$.

Semestrial, the most important amounts of precipitations in the northeastern part of Romania were attributed to the retrogressive cyclones in the Eastern part of Romania and the ridges over the northern part of Europe. So, associated with EZ, during the 2000 to 2018 period, in the cold semester were recorded $28.43 \mathrm{~mm}$ and $27.66 \mathrm{~mm}$ within NEZ. During the warm semester, the highest amounts of precipitations were recorded within the HNFA type, with $42.75 \mathrm{~mm}$, followed by Highs over the British Isles (HB) -25.44 $\mathrm{mm}$. The lowest values were associated with the southerly and southwesterly, both into an anti-cyclonic type (SA, SWA).
\end{abstract}

Keywords: Hess-Brezowsky, precipitations, cyclonic pattern, Moldova.

\section{INTRODUCTION}

The main trigger for all-weather phenomena is linked by namely synoptically types (Donat et al. 2009; Stucki et al. 2012; Hoy et al. 2013; Kornhuber et al. 2019). In this context, those factors underlying the trigger of some weather's aspect are the

\footnotetext{
${ }^{1}$ S.C. INTERVENȚII ACTIVE ÎN ATMOSFERĂ S.R.L. Str. Răcari, Sect. 3, 031828, Bucharest, Romania.nyycu87@yahoo.com; dan.axinte@yahoo.com;

${ }^{2}$ University 'Alexandru Ioan Cuza' Carol It Av. 700505, Iași, Romania. apostolliv@yahoo.com

${ }^{3}$ University of Bucharest Nicolae Bălcescu Av. 010041, Bucharest, Romania
} 
sea level pressure (surface), the geopotential height at $500 \mathrm{hPa}$ (middle troposphere), and the meridional wind velocity at $300 \mathrm{hPa}$ geopotential (upper troposphere) above some areas such as Europe (Hess and Brezowsky 1977; James 2007; Huth et al. 2008). Changes in occurrence frequencies and durations of weather patterns as well as their sequences are already evident and can be likely linked to the ongoing climate changes due to the difference of warming rates between land and ocean (Kysely 2008; Werner et al. 2008; Cahynova and Huth 2009; Hoy et al. 2012; Kucerova et al. 2016; Hoffmann 2017; Murawski et al. 2018). Therefore, once with the global warming, more water evaporates over the ocean areas, conditions where the water vapors into the atmosphere, necessarily for trigging the extreme weather phenomena, are higher (Trenberth 2011; Hattermann et al. 2018; WMO 2019).

At the level of Romania's climate, the atmospheric circulations and their influences were studied over time by different authors with diverse methodologies and techniques to approach (Sfîcă et al., 2015). Cazacioc made a first study that used the Hess-Brezowsky classification to correlate atmospheric circulations with variability and distribution of the maximum precipitations throughout Romania in 2007.

This study evaluates the precipitation amounts recorded in the northern part of Moldavia from 2000 to 2018 interval associated with the Hess-Brezowsky classification (Gerstengarbe; Werner 2010). Using the Hess-Brezowsky classification to find out those weather patterns that generated significant precipitations episodes in the northern part of Moldavia was preferred due to being valid for Romania's territory within the atmospheric circulation level of Central Europe.

\section{DATA AND METHODS}

The data used here are the meteorological observations regarding the precipitations amount recorded at the weather stations from the northeastern part of Romania (fig.1), those being integrated into the synoptic flux. These data were extracted from the daily archive, provided by https://www.ecad.eu/dailydata/customquery.php for Bacau (184 m), Botosani (161 $\mathrm{m})$, Ceahlau-Toaca $(1897 \mathrm{~m})$, Iasi $(102 \mathrm{~m})$. For Suceava weather station, the data used were extracted within the ROCADA grid archive for 2000 to 2013 time-interval (Dumitrescu, Bîrsan 2015), then, until 2018 from the database provided by http://www.meteomanz.com/index?1=1.

The Grosswetterlagen (GWL) concept was proposed by Baur et al. (1944), improved upon, and later revised by Hess and Brezowsky $(1952,1969,1977)$, which is one who includes a large area of analyses with very accurate details.

This classification is particularly fitted for the central part of Europe. Because the northern and northeastern parts of Romania do many of the weather's features from Central Europe, I used this concept Hess-Brezowsky - Grosswetterlagen (HBGWL). 
To make a correlation between the precipitations amount with the HessBrezowsky types, for 2000 to 2009 were taken into account the types made within PIK (Gerstengarbe; Werner 2010). Subsequently, to continue on this way, an analysis for the archive synoptical materials for 1000 and $500 \mathrm{hPa}$ geopotential, provided by http://www1.wetter3.de/ has been made.

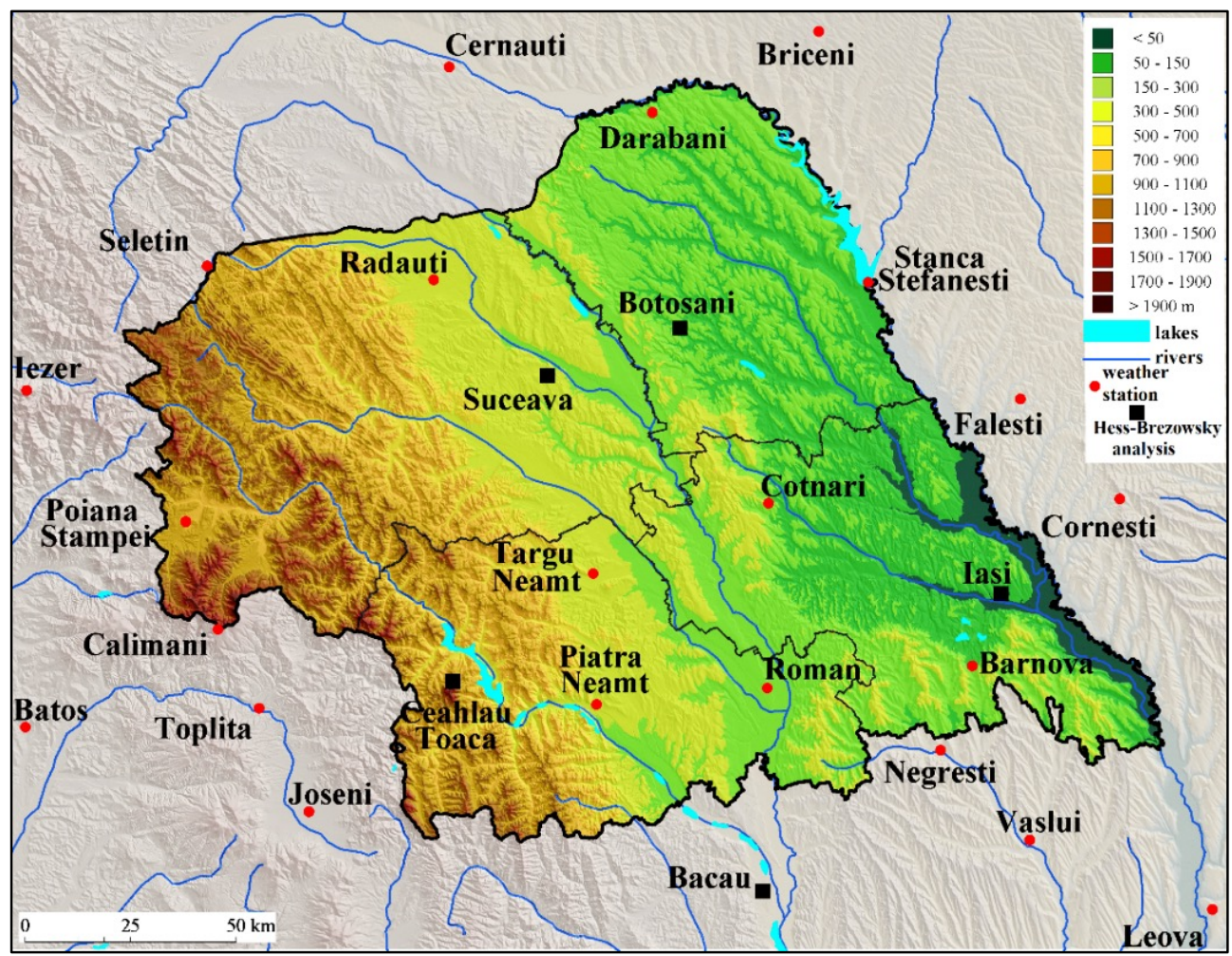

Fig. 1. Location of the studied region with the reference weather stations for HessBrezowsky classification

The Hess-Brezowsky classification includes 29 weather types (tab 1). This classification was correlated with the precipitation amount within the studied area.

Interprets of results were made from the annual to the season's level. In this way, all the types were taken into account by highlighting those associated with extreme precipitation events, such as the highest or lowest amounts recorded between 2000 to 2018 .

In the future, by identifying the synoptic types according to the Hess-Brezowsky classification, it is intended a ranking of them for a longer time-interval to make a useful tool to forecast and assets as better possible all the pluvial risks in the northeastern part of Romania.

Such a study will help local decision-makers, Hydrothenics units, emergency institutions, and farmers. 
Table 1. The 29 Grosswetterlagen types structures

\begin{tabular}{|c|c|c|}
\hline \multicolumn{3}{|c|}{ The 29 Grosswetterlagen structures with English definitions } \\
\hline Type & Indicative & What do they represent \\
\hline \multirow{4}{*}{ West } & WA & Westerly, Anti-cyclonic \\
\hline & WZ & Westerly, Cyclonic \\
\hline & WS & Westerly, Southern \\
\hline & WW & Maritime Westerly (Block E. Europe) \\
\hline \multirow{8}{*}{ South } & SWA & South-Westerly, Anti-cyclonic \\
\hline & SWZ & South-Westerly, Cyclonic \\
\hline & SA & Southerly, Anti-cyclonic \\
\hline & SZ & Southerly, Cyclonic \\
\hline & TB & Low over the British Isles \\
\hline & TRW & Trough over Western Europe \\
\hline & SEA & South-Easterly, Anti-cyclonic \\
\hline & SEZ & South-Easterly, Cyclonic \\
\hline \multirow{8}{*}{$\begin{array}{c}\text { North- } \\
\text { westerly } \\
\text { and North }\end{array}$} & NWA & North-Westerly, Anti-cyclonic \\
\hline & NWZ & North-Westerly, Cyclonic \\
\hline & NA & Northerly Anti-cyclonic \\
\hline & NZ & Northerly, Cyclonic \\
\hline & HNA & Icelandic High, Ridge C. Europe \\
\hline & HNZ & Icelandic High, Trough C. Europe \\
\hline & HB & High over the British Isles \\
\hline & TRM & Trough over Central Europe \\
\hline \multirow{8}{*}{$\begin{array}{l}\text { North- } \\
\text { easterly } \\
\text { and Est }\end{array}$} & NEA & North-Easterly, Anti-cyclonic \\
\hline & NEZ & North-Easterly, Cyclonic \\
\hline & EA & Easterly, Anti-cyclonic \\
\hline & EZ & Easterly, Cyclonic \\
\hline & HFA & Scandinavian High, Ridge C. Europe \\
\hline & HFZ & Scandinavian High, Trough C. Europe \\
\hline & HNFA & High Scandinavia-Iceland, Ridge C. Europe \\
\hline & HNFZ & High Scandinavia-Iceland, Trough C. Europe \\
\hline Blocking & HM & High over Central Europe \\
\hline
\end{tabular}

\section{RESULTS AND DISCUSSIONS}

\subsection{Annual}

Using the precipitations data provided by E-CAD, ROCADA grid (Dumitrescu, Bîrsan 2015), and meteomanz.com for Bacau, Botoșani, Ceahlău-Toaca, Iași, Suceava weather stations in correlation with the Hess-Brezowsky classification for 2000 to 2018 time interval, at the annual level resulted that the highest amounts of precipitations were linked by northeasterly, cyclonic type (NEZ). Within this weather pattern was recorded, the mean amount of precipitations of $53.45 \mathrm{~mm}$. At the level of each weather station, there were recorded values: Botoșani $-58.54 \mathrm{~mm}$, Bacău - $55.27 \mathrm{~mm}$, Iași - $54.51 \mathrm{~mm}$, Suceava - $52.12 \mathrm{~mm}$, and Ceahlău-Toaca $46.81 \mathrm{~mm}$ (fig.2). The values showed the importance of the retrogressive cyclones in that part of Romania during the entire year, especially in the cold semester (Apostol 2008). 
Significant amounts of precipitations were also recorded in the Icelandic Scandinavian highs, with ridge spreading over Europe's central part (HNFA). The mean amounts of precipitation in the studied area were associated with this weather type, which was $48.14 \mathrm{~mm}$. At the weather station's level, in such synoptic type, there were recorded the following amounts of precipitations: Suceava $-71.95 \mathrm{~mm}$, Iasi - 61.77 mm, Botoșani - 48.44 mm, Ceahlău-Toaca - 42.69 mm, Bacău - 15.84 mm. Although the HNFA type owns a small percentage for the 2000 to 2018 interval, its activity was associated with high-pressure areas placed over Europe's northern part. The southern parts of the continent were under low-areas action. The low-areas from the southern part of Europe had a long time of action until 6 to 7 days. Those types' more intensive action was noticed during the transition season (spring and fall).

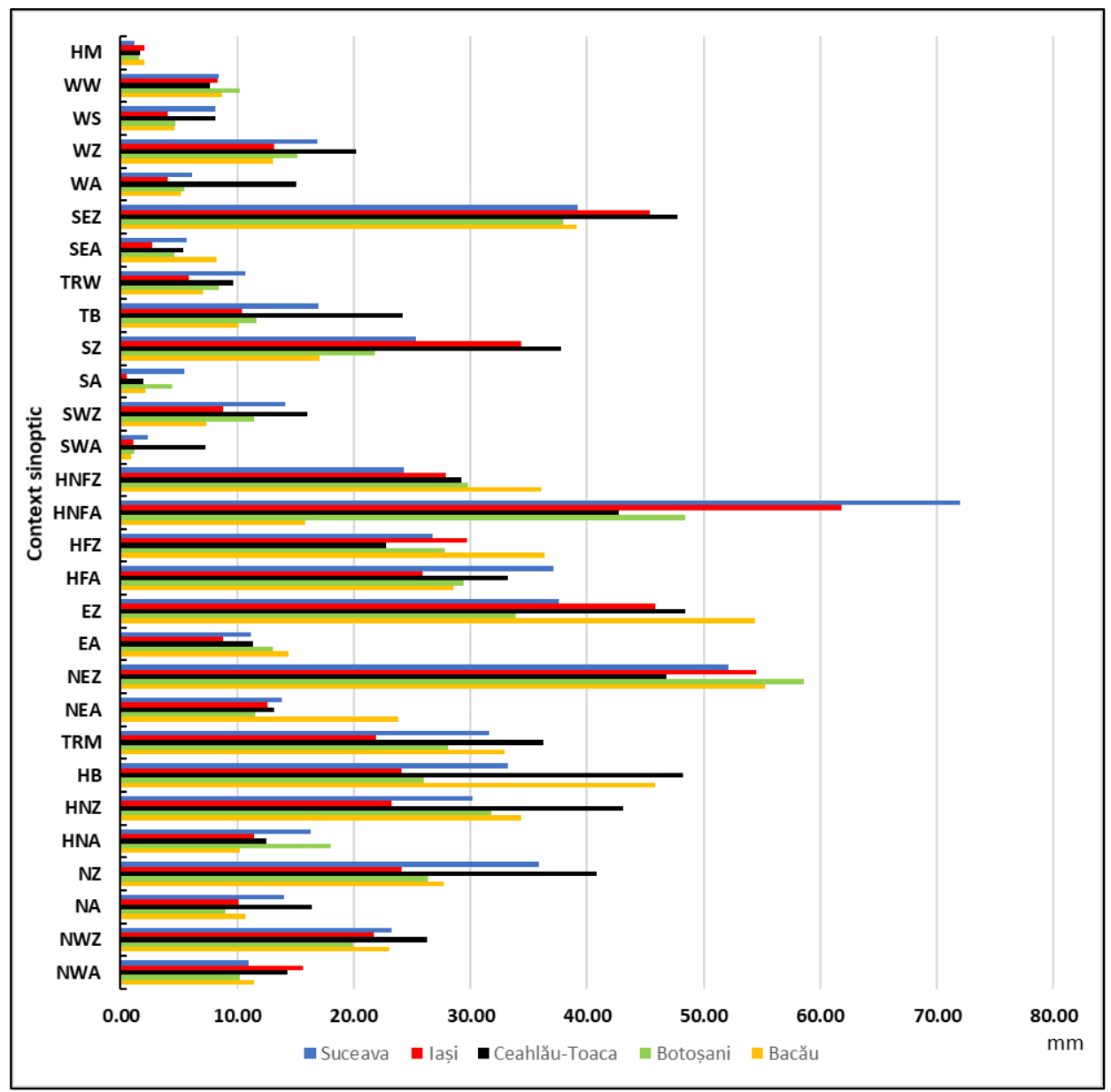

Fig. 2. Annual mean amounts of precipitation in the northern part of Moldavia by Hess-Brezowsky classification for 2000 to 2018 
By major importance are the synoptic cases that generate the drought phenomenon into the studied area, too. For the time interval studied, the lowest amounts of precipitations were associated with the blocking over Central Europe type (HM). In that case, the mean amounts of precipitation didn't exceed values higher than $1.80 \mathrm{~mm}$, that like a region's average. Small precipitation values were also associated with the southwesterly and south, both of them into anti-cyclonic type (SWA, SA). And this time, the values didn't exceed $2.00 \mathrm{~mm}$ into the investigated area.

Such atmospheric patterns are associated with the high-pressure areas over the central-south parts of Europe. Such patterns have a higher frequency during the cold semester, with 8 to $12 \%$, with the highest intensity in the wintertime of 13 to $15 \%$. In that moment of the year, the 'Omega' blocks that occur over Europe's centralsouth parts can be considered.

\subsection{Semestrial}

To analyzing the synoptical patterns at the semestrial level, there can be noticed a series of features. Figure 5 shows that the highest weight of precipitations is concentrated during the warm semester.

The correlation between precipitation amounts with the Hess-Brezowsky atmospheric circulation types highlighted that the most significant amount of precipitations during the cold semester were recorded with retrogressive cyclones. So, within the northeasterly and easterly, both of them into the cyclonic type (NEZ, EZ), the mean values in the studied area were $28.43 \mathrm{~mm}$, and $27.66 \mathrm{~mm}$, respectively.

Insignificant amounts of precipitations were liked by southwesterly and southerly, both of them in cyclonic atmospheric circulation type (SWA, SA). The average amount of precipitation in the studied area during the cold semester didn't exceed $1.00 \mathrm{~mm}$.

Besides the HM, the WA and HNA pattern represent the main vectors for drought set-up in the cold semester's studied area.

Due to a more intense atmospheric velocity, the warm semester shows the highest weight of the studied area's precipitations. There can be pointed out more types that are linked with significant amounts of precipitations in such circumstances.

A significant amount of precipitations was associated with the HNFA type, 42.75 $\mathrm{mm}$, as an average over the entire area. The most representative amounts of precipitations linked by this type were recorded at Suceava - $66.13 \mathrm{~mm}$ and Iași $56.83 \mathrm{~mm}$.

Major importance for high amounts of precipitations in the northern part of Moldavia was in the HB (High over the British Isles) when the average at the studied area's level was $25.44 \mathrm{~mm}$. In the order regarding the high amounts of precipitations following the HNZ (Icelandic high, a trough over Central Europe) with $25.34 \mathrm{~mm}$ and TRM (trough over Central Europe) with $22.24 \mathrm{~mm}$. All of them are associated, in many cases, with heavy precipitations (Cazacioc 2007). 


\begin{tabular}{|c|c|c|c|c|c|c|c|c|c|c|}
\hline \multirow{2}{*}{$\begin{array}{c}\text { Weather station } \\
\text { Season/type }\end{array}$} & \multicolumn{2}{|c|}{ Bacău } & \multicolumn{2}{|c|}{ Botoșani } & \multicolumn{2}{|c|}{ Ceahlău } & \multicolumn{2}{|c|}{ Iași } & \multicolumn{2}{|c|}{ Suceava } \\
\hline & Cold & Warm & Cold & Warm & Cold & Warm & Cold & Warm & Cold & Warm \\
\hline NWA & 2.02 & 9.41 & 2.47 & 7.78 & 3.29 & 11.03 & 2.93 & 12.72 & 2.49 & 8.54 \\
\hline NWZ & 8.79 & 14.30 & 6.70 & 13.23 & 9.43 & 16.82 & 11.18 & 10.55 & 6.98 & 16.29 \\
\hline NA & 3.87 & 6.84 & 2.76 & 6.26 & 3.44 & 12.99 & 3.06 & 7.09 & 3.04 & 10.98 \\
\hline $\mathrm{NZ}$ & 11.80 & 15.88 & 11.26 & 15.15 & 13.54 & 27.27 & 10.54 & 13.59 & 13.50 & 22.41 \\
\hline HNA & 1.59 & 8.61 & 5.17 & 12.81 & 1.76 & 10.78 & 2.64 & 8.84 & 2.63 & 13.70 \\
\hline HNZ & 4.33 & 30.07 & 8.56 & 23.26 & 6.53 & 36.54 & 9.14 & 14.10 & 7.41 & 22.75 \\
\hline $\mathrm{HB}$ & 11.39 & 34.48 & 9.66 & 16.30 & 10.35 & 37.88 & 8.60 & 15.49 & 10.19 & 23.06 \\
\hline TRM & 9.03 & 23.94 & 7.58 & 20.49 & 9.48 & 26.74 & 6.48 & 15.45 & 7.07 & 24.57 \\
\hline NEA & 5.61 & 18.20 & 5.07 & 6.49 & 3.76 & 9.41 & 5.13 & 7.48 & 4.27 & 9.55 \\
\hline NEZ & 31.62 & 23.64 & 32.42 & 26.12 & 18.26 & 28.55 & 34.95 & 19.55 & 21.05 & 31.08 \\
\hline EA & 10.18 & 4.25 & 6.79 & 6.31 & 5.85 & 5.55 & 5.43 & 3.42 & 6.70 & 4.46 \\
\hline EZ & 35.56 & 18.86 & 26.22 & 7.66 & 24.35 & 24.05 & 31.42 & 14.42 & 24.61 & 12.99 \\
\hline HFA & 16.90 & 11.69 & 12.00 & 17.38 & 11.89 & 21.36 & 12.15 & 13.79 & 11.25 & 25.90 \\
\hline HFZ & 15.71 & 20.68 & 8.48 & 19.32 & 6.56 & 16.22 & 17.43 & 12.25 & 13.49 & 13.28 \\
\hline HNFA & 6.55 & 9.30 & 7.85 & 40.58 & 1.79 & 40.91 & 4.95 & 56.83 & 5.81 & 66.13 \\
\hline HNFZ & 17.52 & 18.58 & 10.26 & 19.50 & 12.90 & 16.33 & 14.67 & 13.21 & 9.07 & 15.24 \\
\hline SWA & 0.46 & 0.45 & 1.12 & 0.04 & 1.28 & 5.98 & 0.32 & 0.80 & 0.99 & 1.36 \\
\hline SWZ & 2.84 & 4.54 & 4.05 & 7.46 & 5.33 & 10.70 & 3.78 & 5.02 & 3.53 & 10.56 \\
\hline SA & 1.13 & 1.07 & 1.05 & 3.35 & 0.76 & 1.21 & 0.55 & 0.00 & 0.88 & 4.60 \\
\hline SZ & 8.97 & 8.11 & 9.65 & 12.20 & 8.68 & 29.11 & 11.53 & 22.86 & 9.28 & 16.06 \\
\hline TB & 3.43 & 6.67 & 2.66 & 9.04 & 4.50 & 19.68 & 3.45 & 6.96 & 4.26 & 12.76 \\
\hline TRW & 1.59 & 5.55 & 3.38 & 5.09 & 2.43 & 7.19 & 2.40 & 3.49 & 3.75 & 6.93 \\
\hline SEA & 4.01 & 4.21 & 2.41 & 2.20 & 2.15 & 3.19 & 2.34 & 0.42 & 2.33 & 3.30 \\
\hline SEZ & 23.89 & 15.22 & 29.27 & 8.74 & 15.27 & 32.44 & 31.60 & 13.77 & 21.01 & 18.20 \\
\hline WA & 2.95 & 2.28 & 1.68 & 3.84 & 2.34 & 12.73 & 1.78 & 2.27 & 1.76 & 4.42 \\
\hline WZ & 4.29 & 8.82 & 3.62 & 11.53 & 5.70 & 14.54 & 5.38 & 7.82 & 4.66 & 12.19 \\
\hline WS & 4.11 & 0.52 & 3.72 & 1.03 & 5.83 & 2.28 & 3.27 & 0.83 & 5.41 & 2.72 \\
\hline WW & 8.67 & 0.00 & 10.20 & 0.00 & 7.69 & 0.00 & 8.37 & 0.00 & 8.38 & 0.00 \\
\hline HM & 2.06 & 0 & 1.52 & 0.03 & 1.65 & 0.00 & 2.08 & 0.00 & 1.19 & 0.00 \\
\hline
\end{tabular}

Fig. 3. Semestrial mean amounts of precipitation in the northern part of Moldavia by Hess-Brezowsky classification for 2000 to 2018

All the patterns featured by small amounts of precipitations (under $1.25 \mathrm{~mm}$ ) were associated with southerly and southwesterly (SA, SWA), and the blocking (HM) atmospheric circulation types.

\subsection{Seasonal}

At the seasonal level, important amounts of precipitations during the springtime were mainly associated with the northwesterly cyclonic atmospheric circulation types and retrogressive cyclones.

In doing so, the highest mean amounts of precipitations in the studied area during the spring were associated with $\mathrm{HB}-12.52 \mathrm{~mm}$, TRM $-9.82 \mathrm{~mm}$, EZ (cyclonic easterly) $-9.42 \mathrm{~mm}$, and NEZ $-9.22 \mathrm{~mm}$. Small values were associated with the block (HM) and anti-cyclonic south or/and southwesterly atmospheric circulation types (SA, SWA, fig. 4).

When the atmosphere's energetic potential shows the highest rate in the summertime, the unstable rate is high. So, the majority of the cyclonic patterns were linked with high amounts of precipitations. 


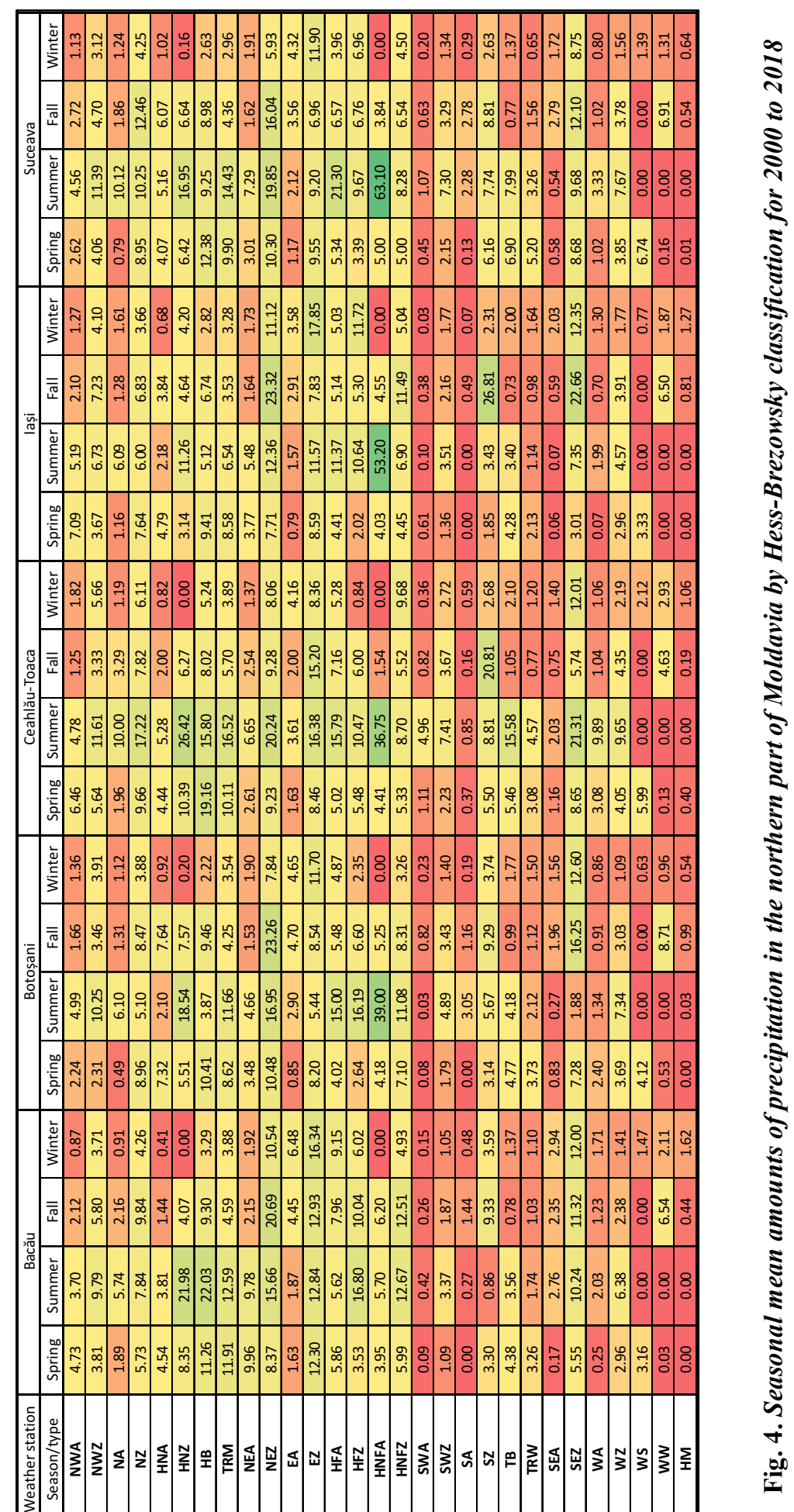


One of those was associated with the HNFA type, where the mean amounts of precipitations over the entire area studied was $39.55 \mathrm{~mm}$. The low area's action gives that context over Europe's central-southeasterly parts and high-pressure areas over the continent's northern part. The HNFA types are linked with unstable weather periods over the northeastern part of Romania. As a result, heavy precipitations generate flash floods and floods. The life-time of such synoptic types can be from 4 to 12 days.

The absence and/or small amounts of precipitations are associated with HM and southeasterly into anti-cyclonic atmospheric circulation types (SEA).

During the fall and winter, the most favorable conditions for significant amounts of precipitations are associated with the lows linked by retrogressive cyclones. As a result, in that period of the year (fall), take place a strengthening of the Mediterranean cyclogenesis. That shows a decrease in intensity during the first half of the winter, then to increase again in February and the first half of the spring (Apostol 2008).

The synoptic pattern associated with important amounts of precipitations in the northeastern part of Romania were into the NEZ case, with an average amount of $18.52 \mathrm{~mm}$, followed by that from the south into cyclonic atmospheric circulation type (SZ), with $15.01 \mathrm{~mm}$. The second pattern (SZ), as a result, due to the strengthening of the Mediterranean cyclogenesis. By such synoptic patterns, Romania's northeastern part is characterized by clouded, humid, and warm weather. In those contexts, the precipitations will be predominately rain.

During the winter, important amounts of precipitations were linked with the cyclonic easterly atmospheric circulation type (EZ). Therefore, when such airmasses circulations occurred, the mean amounts of precipitations in the studied area was $13.23 \mathrm{~mm}$. Also, high amounts of precipitations were into the southeasterly, associated with cyclonic atmospheric circulation type (SEZ) - $11.54 \mathrm{~mm}$. During the fall and winter, the small amounts or absence of precipitations are associated with HM, SA, SWA, and even the WS (Westerly-southern) atmospheric circulation types.

\section{CONCLUSIONS}

The purpose of this study was to show the synoptic patterns associated with the amounts of precipitations for the northeastern part of Romania (more exactly, the northern part of Moldavia). There were highlighted the synoptic patterns linked with the highest and lowest amounts of precipitations.

The results show that the highest mean amounts of precipitations during the entire year were linked by northeasterly, cyclonic atmospheric circulation type (NEZ), with a mean value for the entire area around $53.45 \mathrm{~mm}$. Also, important amounts of precipitations were recorded in HNFA type, with $48.14 \mathrm{~mm}$.

At the semestrial level, during the cold semester, the results show that the highest amounts of precipitations were recorded into the easterly, cyclonic type (EZ) - 28.43 $\mathrm{mm}$, followed by those from northeasterly, cyclonic atmospheric circulation type (NEZ) - 27.66 mm. During the warm semester, the highest amounts of precipitations 
were recorded when a High Icelandic-Scandinavia with a ridge over Central Europe (HNFA) occurred, when there was recorded $42.75 \mathrm{~mm}$. Further, that pattern was followed by High Scandinavian with Trough over Central Europe (HNZ) - 25.44 $\mathrm{mm}$, and Trough over Central Europe (TRM) - $22.44 \mathrm{~mm}$. The latter was often associated with cases when the region of Romania was placed into an unstable but warm air-mass when severe weather phenomena occur.

During the spring season, the region's highest amounts of precipitations were recorded into cyclonic northwesterly atmospheric circulation type. In this way, by importance, the High over the British Isles (HB) - $12.52 \mathrm{~mm}$ and northerly, cyclonic atmospheric circulation type (NZ) $-8.19 \mathrm{~mm}$. Once the cyclonic activity gets more intense over the Mediterranean Sea, a major importance is represented by easterly, cyclonic atmospheric circulation type (EZ) - $9.42 \mathrm{~mm}$ and NEZ - $9.22 \mathrm{~mm}$.

In the summertime, the most important amounts of precipitations in the studied area were associated with HNFA pattern - $39.55 \mathrm{~mm}$, followed by HNZ pattern $19.03 \mathrm{~mm}$. The low pressures areas are associated with the highest amounts of precipitations over the Mediterranean Sea during the fall and winter. As a result, the most representative in this way are the NEZ, EZ, and SEZ patterns.

Conversely, the lowest or nonexistent values are associated with settling of a ridge over Central and South Europe from the annual to seasonal level. As a result, in the studied area prevail the Southwesterly, anti-cyclonic atmospheric circulation type (SWA), Southerly, anti-cyclonic atmospheric circulation type (SA), Westerly, anti-cyclonic atmospheric circulation type (WA), and Blocking over Central Europe (HM) pattern.

\section{ACKNOWLEDGEMENTS}

This work was co-funded by the European Social Fund, through Operational Programme Human Capital 2014-2020; project number POCU/380/6/13/123623, project title 'PhD Students and Postdoctoral Researchers Prepared for the Labor Market'

\section{REFERENCES}

1. Apostol L. (2008), The Mediterranean cyclones - the role in ensuring water resources and their potential of climatic risk, in the east of Romania. Present Environment and Sustainable Development. 2, 143-163.

2. Baur F., Hess P., Nagel H. (1944), Kalendar der Grosswetterlagen Europas 18811939. Bad Homburg (DWD).

3. Cahynova M., Huth R. (2009), Enhanced lifetime of atmospheric circulation types over Europe: fact or fiction? Tellus A 61(3):407-416. https://doi.org/10.1111/j.16000870.2009.00393.x.

4. Cazacioc L. (2007), Spatial and temporal variability of extreme daily precipitation amounts in Romania, România.

5. Donat M.G, Leckebusch G.C, Pinto J.G, Ulbrich U. (2009), Examination of wind storms over Central Europe with respect to circulation weather types and NAO 
phases. International Journal of Climatology, pp n/a-n/a. https://doi.org/10.1002/joc.1982.

6. Dumitrescu A., Birsan M.V. (2015), ROCADA: A gridded daily climatic dataset over Romania (1961-2013) for nine meteorological variables. Nat. Hazards, 78, 10451063.

7. Gerstengarbe F., Werner P. (2010), Katalog der Großwetterlagen Europas nach Paul Hess und Helmuth Brezowski, PIK, Germany.

8. Hattermann F.F., Wortmann M., Liersch S., Toumi R., Sparks N., Genillard C., Schroter K., Steinhausen M., Gyalai-Korpos M. M., Hayes B., del Rocio Rivas Lopez M., Nielsen M.R., Kaspersen P.S., Drews M. (2018), Simulation of flood hazard and risk in the Danube basin with the future Danube model. Climate Services 12:14-26. https://doi.org/10.1016/j.cliser.2018.07.001.

9. Hess P., Brezowsky H. (1952), Katalog der Grosswetterlagen Europas. Berichte des Deutschen Wetterdienstes in der US-Zone. 33.

10. Hess P., Brezowsky H. (1977), Katalog der Grosswetterlagen Europas 1881-1976. 3. Verbesserte und erg€anzte Aufl. Berichte des Deutschen Wetterdienstes 113. Offenbach .am Main.

11. *** (1969), Katalog der Grosswetterlagen Europas. 2. neu bearbeitete und erg€anzte Aufl. Berichte des Deutschen Wetterdienstes 113. Offenbach am Main.

12. Hoffmann P. (2017), Enhanced seasonal predictability of the summer mean temperature in Central Europe favored by new dominant weather patterns. Clim. Dyn. 50(7-8):2799-2812. https://doi.org/10.1007/s00382-017-3772-0.

13. Hoy A, Sepp M, Matschullat J (2012), Atmospheric circulation variability in Europe and Northern Asia (1901 to 2010). Theor. Appl. Climatol. 113(1-2):105-126. https://doi.org/10.1007/s00704-012-0770-3.

14. Hoy A., Schucknecht A., Sepp M., Matschullat J. (2013), Large-scale synoptic types and their impact on European precipitation. Theor. Appl. Climatol. 116(1-2):19-35. https://doi.org/10.1007/s00704-013-0897-x.

15. Huth R., Beck C., Philipp A., Demuzere M., Ustrnul Z., Cahynova M., Kysely J., Tveito O.E. (2008), Classifications of atmospheric circulation patterns. Ann N Y Acad Sci 1146(1):105-152. https://doi.org/10.1196/annals.1446.019.

16. James P.M. (2007), An objective classification method for Hess and Brezowsky Grosswetterlagen over Europe. Theor. Appl. Climatol. 88:17-42. https://doi.org/10.1007/s00704-006-0239-3.

17. Kornhuber K., Osprey S., Coumou D., Petri S., Petoukhov V., Rahmstorf S., Gray L. (2019), Extreme weather events in early summer 2018 connected by a recurrent hemispheric wave-7 pattern. Environmental Research Letters 14(5):054,002. https://doi.org/10.1088/1748-9326/ab13bf.

18. Kucerova M., Beck C., Philipp A., Huth R. (2016), Trends in frequency and persistence of atmospheric circulation types over Europe derived from a multitude of classifications. International Journal of Climatology 37(5):2502-2521. https://doi.org/10.1002/joc.4861.

19. Kysely J. (2008), Influence of the persistence of circulation patterns on warm and cold temperature anomalies in Europe: analysis over the 20th century. Glob Planet Chang 62(1-2):147-163. https://doi.org/10.1016/j.gloplacha.2008.01.003.

20. Murawski A., Vorogushyn S., B"urger G., Gerlitz L., Merz B. (2018), Do changing weather types explain observed climatic trends in the Rhine basin? an analysis of within- and between-type changes. Journal of Geophysical Research: Atmospheres. https://doi.org/10.1002/2017jd026654. 
21. Sfica L., Nita A., Iordache I., Ilie N. (2015), Specific weather conditions on Romanian territory for Hess - Brezowsky westerly circulation types. 15th International Multidisciplinary Scientific GeoConference SGEM 2015, Conference Proceedings, ISBN 978-619-7105-38-4 / ISSN 1314-2704, June 18-24, Book4, 1073-1080.

22. Stucki P., Rickli R., Bronnimann S., Martius O., Wanner H., Grebner D., Luterbacher $\mathrm{J}$, (2012), Weather patterns and hydro-climatological precursors of extreme floods in Switzerland since 1868. Meteorologische Zeitschrift 21(6):531-550. https://doi.org/10.1127/0941-2948/2012/368.

23. Trenberth K. (2011), Changes in precipitation with climate change. Clim. Res. 47(1):123-138. https://doi.org/10.3354/cr00953.

24. Werner P., Gerstengarbe F.W., Wechsung F. (2008), Grosswetterlagen-wetterlagen and precipitation trends in the Elbe River catchment. Meteorol. Z 17(1):061-066. https://doi.org/10.1127/0941-2948/2008/0263.

25. WMO (2019), The global climate in 2015-2019. World Meteorological Organization. 26. https://www.ecad.eu/dailydata/customquery.php

27. http://www.meteomanz.com/index?1=1 